\title{
KRONIKA
}

ELŻBIETA KWIATKOWSKA

Wydział Nauk Pedagogicznych

Uniwersytet Kardynała Stefana Wyszyńskiego w Warszawie

ORCID ID: http://orcid.org/oooo-0oo2-8509-9120
Forum Pedagogiczne $2018 / 2$

Wpłynęło: 11.06.2018 Zatwierdzono do druku: 26.09.2018 DOI: 10.21697/fp.2018.2.27

\section{Międzynarodowa konferencja naukowa pt. „Polish Britain: Multilingualism and Diaspora Community" (Cambridge, 9 lutego 2018 roku)}

Mobilność Polaków, od czasu wstąpienia Polski do Unii Europejskiej, zgodnie z danymi GUS, wciąż wzrasta. Według szacunkowego opracowania GUS, pod koniec 2016 roku poza granicami Polski przebywało czasowo około 2515 tys. Polaków, tj. o 118 tys. (4,7 proc.) więcej niż w 2015 roku. Wśród krajów europejskich najwięcej osób emigruje do Wielkiej Brytanii. W samym roku 2016 odnotowano wzrost o 68 tys. osób, tj. o 9,4 proc. więcej niż w roku 2015. W 2016 roku w Wielkiej Brytanii przebywało 788 tys. Polaków, co stanowi największą grupę narodową w UK (GUS 2017).

Zmiany gospodarcze i społeczne w Europie, fala migracji zarobkowych, w tym do Wielkiej Brytanii, prowadzą do podejmowania inicjatyw, również naukowych, mających na celu analizę i diagnozę nowych struktur społecznych, wyzwań, problemów i możliwości związanych z tworzeniem się nowego typu społeczeństw różnorodnych kulturowo.

W dniu 9 lutego 2018 roku w Cambridge University odbyła się międzynarodowa konferencja pt. „Polish Britain: Multilingualism and Diaspora Community”, poświęcona tematowi wielojęzyczności w polskiej społeczności funkcjonującej w Wielkiej Brytanii. Polskie rodziny znajdują się bowiem w szczególnej sytuacji, ich członkowie doskonalą umiejętności komunikacyjne w języku angielskim (na różnych poziomach), pielęgnując jednocześnie kulturę i język polski. Szczególnym wyzwaniem są rodziny, których potomstwo urodziło się w Wielkiej Brytanii, funkcjonuje w angielskim systemie edukacji, jednocześnie osadzone jest w polskiej rodzinie, porozumiewającej się na co dzień w języku polskim. Inne przypadki to rodziny, związki, w których tylko jedna osoba jest polskiego pochodzenia, druga zaś porozumiewa się w języku angielskim, potomstwo jest natomiast pomostem łączącym dwie kultury, dwa języki. Funkcjonowanie dzieci i dorosłych w tych szczególnych okolicznościach było przedmiotem rozważań podczas konferencji, która odbyła się w ramach projektu badawczego Cambridge University: „Multilingualism: Empowering Individuals, Transforming Societies” („Wielojęzyczność: wzmacnianie jednostek, przekształcanie społeczeństw”, MEITS), przeprowadzonego w ramach inicjatywy badawczej „Open World Research AHRC”. Kompetencje językowe w więcej niż jednym języku, tzw. wielojęzyczność, stanowią obecnie centrum badań lingwistów, 
literatów, psychologów i pedagogów. Wychodzenie poza jeden język, związany silnie z kulturą, sposobem myślenia, a także pośrednio z funkcjonowaniem społecznym, to zjawisko coraz mocniej zakorzenione w jednostkach i społeczeństwach europejskich.

Gospodarzami konferencji byli dr Stanley Bill oraz Edyta Nowosielska, pracownicy Cambridge University, zajmujący się literaturą i kulturą narodów słowiańskich, a przede wszystkim kulturą polską. Spotkanie otworzyła prof. Wendy Ayres-Bennett, współprowadząca projekt MEITS. Spotkanie podzielono na cztery sesje tematyczne. Podczas pierwszej z nich, poświęconej zagadnieniom dwujęzyczności osób polskiego pochodzenia, uczących się lub pracujących w Wielkiej Brytanii, wystąpiły: dr Elwira Grossman (University of Glasgow), dr Anna Seretny (Uniwersytet Jagielloński) oraz prof. Yaron Matras (University of Manchester). Sesja druga koncentrowała się na psychologicznych i neurologicznych aspektach dwujęzyczności. W tej części konferencji głos zabrali: dr Thomas Bak (University of Edinburgh), dr Zofia Wodniecka (Uniwersytet Jagielloński) oraz dr Lisa-Maria Müller (University of Cambridge). Konferencja łączyła kwestię wielojęzyczności z szerszymi zagadnieniami migracji i społeczeństwa wielokulturowego w Europie. W trzeciej sesji naukowej podjęto rozważania dotyczące funkcjonowania obcokrajowców uczących się języka polskiego, analizując diagnozowaną w badaniach własnych sytuację ukraińskich migrantów w Polsce.

W tej części konferencji głos zabrali: Miroslava Keryk, prezes fundacji Nasz Wybór, wspierającej mniejszość ukraińską w Polsce, dr Elżbieta Kwiatkowska (Uniwersytet Kardynała Stefana Wyszyńskiego w Warszawie) oraz dr Katarzyna Zechenter (University College London). Czwarta sesja konferencji koncentrowała się na nowych stylach komunikacji międzyludzkiej, w kontekście krzyżowania się i przeobrażania języków w środowiskach różnorodnych kulturowo. Badania własne w tym zakresie zaprezentowali dr Kinga Koźmińska (University of London), dr Anna Martowicz (Association for the Promotion of Polish Language Abroad) oraz dr Jan Feller (University of Oxford).

Każda z przedstawionych sekcji przebiegała według ustalonego porządku: wystąpienia prelegentów stanowiły wstęp do dyskusji otwartych, podczas których liczna publiczność, przede wszystkim ze środowiska akademickiego Cambridge, oraz bardzo liczna reprezentacja mniejszości polskiej w Wielkiej Brytanii, zadawała pytania, przedstawiała swoje komentarze i stanowiska. Finałową część spotkania stanowiła dyskusja zamykająca, podsumowująca konferencję. W tej części głos zabrali: prof. Anna White (University College London), Krystyna Olliffe (Polish Education Society) oraz Jakub Krupa (PAP).

Organizatorzy konferencji, dbając o dobór tematów i zakresów wystąpień, umożliwili uczestnikom szerokie spojrzenie na zjawisko mieszania, przenikania się kultur, będące jednym z wielu następstw natury społecznej, mobilności mieszkańców krajów europejskich. Proces ten stawia przed decydentami nowe wyzwania dotyczące projektowania rozwiązań edukacyjnych, które dotyczą osób dwujęzycznych, ich trudności, potrzeb oraz ich ogromnego potencjału. 